\title{
Preliminary development of the Higher Education Hindrance Demands Scale amongst academics in the South African context
}

\begin{tabular}{|c|c|}
\hline \multicolumn{2}{|c|}{ 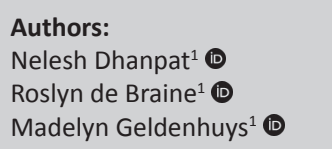 } \\
\hline \multicolumn{2}{|c|}{$\begin{array}{l}\text { Affiliations: } \\
{ }^{1} \text { Department of Industrial } \\
\text { Psychology and People } \\
\text { Management, College of } \\
\text { Business and Economics, } \\
\text { University of Johannesburg, } \\
\text { Johannesburg, South Africa }\end{array}$} \\
\hline \multicolumn{2}{|c|}{$\begin{array}{l}\text { Corresponding author: } \\
\text { Nelesh Dhanpat, } \\
\text { neleshd@uj.ac.za }\end{array}$} \\
\hline \multicolumn{2}{|c|}{$\begin{array}{l}\text { Dates: } \\
\text { Received: } 12 \text { Oct. } 2018 \\
\text { Accepted: } 29 \text { Mar. } 2019 \\
\text { Published: } 18 \text { June } 2019\end{array}$} \\
\hline \multicolumn{2}{|c|}{$\begin{array}{l}\text { How to cite this article: } \\
\text { Dhanpat, N., De Braine, R., \& } \\
\text { Geldenhuys, M. (2019). } \\
\text { Preliminary development } \\
\text { of the Higher Education } \\
\text { Hindrance Demands Scale } \\
\text { amongst academics in } \\
\text { the South African context. } \\
\text { SA Journal of Industrial } \\
\text { Psychology/SA Tydskrif vir } \\
\text { Bedryfsielkunde, 45(0), } \\
\text { a1595. https://doi.org/ } \\
\text { 10.4102/sajip.v45i0.1595 }\end{array}$} \\
\hline \multicolumn{2}{|c|}{$\begin{array}{l}\text { Copyright: } \\
\text { (c) 2019. The Authors. } \\
\text { Licensee: AOSIS. This } \\
\text { is licensed under the } \\
\text { Creative Commons } \\
\text { Attribution License. }\end{array}$} \\
\hline \multicolumn{2}{|l|}{ Read online: } \\
\hline 回得回 & $\begin{array}{l}\text { Scan this QR } \\
\text { code with your } \\
\text { smart phone or } \\
\text { mobile device } \\
\text { to read online. }\end{array}$ \\
\hline
\end{tabular}

Orientation: Over the past two decades, since the advent of democracy in South Africa, the country has undergone transformation in virtually all sectors of society. Education is no exception, with higher education institutions (HEIs) also experiencing change. The transformation of HEIs has brought about many new challenges, demands and stresses that may hinder the work performance of academics.

Research purpose: This study seeks to determine the 'hindrance demands' unique to the South African context by developing and validating the Higher Education Hindrance Demands Scale (HEHDS). This scale includes a set of demands placed on academics' experiences in this context.

Research approach, design and method: Data were collected from 184 academic staff members from HEIs based on a quantitative research design using a cross-sectional survey. Data were analysed through exploratory factor analysis (EFA), while the reliability of the scale was obtained through Cronbach's coefficient alpha.

Main findings: The results produced, as anticipated, a six-factor model consisting of: (1) workload, (2) higher education unrest, (3) change management, (4) decolonisation, (5) online teaching and learning and (6) psychological safety. The findings indicated excellent reliability, ranging between 0.74 and 0.90 .

Practical and managerial implications: Taking into consideration the context in which HEIs operate in South Africa, it is noteworthy that the recommendations in this article will assist in identifying the hindrance demands placed on academic staff. Researchers in the field are therefore called to validate the instrument developed through the use of confirmatory factor analysis.

Contributions or value-add: This study adds to the limited research on hindrance demands placed on staff in HEIs.

Keywords: Hindrance demands; higher education institutions; academic work; job demands; exploratory factor analysis; test construction.

\section{Introduction}

There is an increase in the demand for higher education and this seems to be a worldwide phenomenon (Altbach, Resiburg, \& Rumbley, 2010; Guruz, 2011; Schofer \& Meyer, 2005). Since the transition of apartheid to democracy, higher education institutions (HEIs) in South Africa have undergone significant transformation (Herbst \& Conradie, 2011) and remain in the process of being reformed and restructured (Badat, 2010; King, Margison, \& Naidoo, 2011). Change that occurs in higher education brings about the perception that overall improvement is taking place (Van Niekerk \& Geertsema, 2009); however, this places greater levels of stress on HEI staff and, specifically, academics.

South African HEIs were impacted by structural changes, which resulted from the mergers of technikons and universities. This led to an increase in bureaucracy (Debowski, 2007), which has impacted institutions and employees (Arnold, Stofile, \& Lillah, 2013; Pienaar \& Bester, 2006). These changes have placed various demands on academics in South Africa. Such changes are likely to impact employees' work as they experience specific career dilemmas, namely, increased levels of job dissatisfaction (Phillips \& Connell, 2003), intention to leave, breach of psychological 
contracts, break in employee-employer relationships, decline in commitment and job security, and increased workload (Theron \& Dodd, 2011).

In order for HEIs to be effective, the successful functioning and sustainability of any institution is significantly influenced by the careers of academic staff and their retention $\left(\mathrm{Ng}^{\prime}\right.$ ethe, Amusonge, \& Iravo, 2012). Academic work is characterised as being self-managed, intrinsically motivating and highly individualised. Such work requires high levels of personal commitment (Bellamy Morley, \& Watty, 2003; Langford, Ref; Lyons \& Ingersoll, 2010; Oshagbemi, 2000; Van Theron, Barkhuizen, \& Du Plessis, 2014).

Academics have experienced an increase in their workload due to the high volume of students, demands from other academic staff and the pressure to produce increased research output (Barkhuizen, Rothmann, \& Van De Vijver, 2014; Kenny \& Fluck, 2014), which may prove to be counterproductive for some academics (Munro, O'Meara, \& Kenny, 2016). Employees in an academic setting may therefore experience a unique set of challenges and thus be exposed to varying pressures compared to their nonacademic counterparts (for instance, employees within the corporate sector).

It is evident that today's academia presents a stressful environment (Kinman \& Jones, 2003; Mostert, Rothmann, Mostert, \& Nell, 2008; Rothmann \& Jordaan, 2006). The unique context of transformation in South Africa places additional stress on academics, which is likely to lead to burnout (Rothmann \& Barkhuizen, 2008) and psychological ill health (Jackson, Rothmann, \& Van De Vijver, 2006; Mahomed \& Naudé, 2006).

In terms of the South African context, various studies exist, which focus on HEIs with regard to job demands and job resources (Barkhuizen, Roodt, \& Schutte, 2014), work engagement of academics (Bezuidenhout \& Cilliers, 2010; Pienaar \& Bester, 2006; Rothmann \& Jordaan, 2006), workrelated well-being (Jackson et al., 2006) and occupational stress experienced by academics (Barkhuizen \& Rothmann, 2008; Coetzee \& Rothmann, 2005). However, none of these studies have documented the effects of the hindrance demands on academics, hence the rationale for the current study. With the development of the 'hindrance demands' scale, the study aims to measure more specific demands placed on academics. The value of such a scale will be its ability to provide insights into these challenges and the way in which they are perceived. The study therefore sets out to identify specific hindrance demands specific to the South African academia context, such as workload, higher education unrest, change management, decolonisation, online teaching and learning and psychological safety. Hence, there is the need to develop and validate the hindrance demands scale for higher education.

\section{Study objectives}

The objectives of the study can be formulated as follows:

- to theoretically discuss demands placed on staff in higher education within a South African context.

- to evaluate the construct validity of the Higher Education Hindrance Demands Scale (HEHDS) through exploratory factor analysis.

\section{Hindrance demands}

Hindrance demands are a set of demands that can be framed within the Job Demands-Resources (JD-R) model. According to Bakker and Demerouti (2007), demands within this model are considered as stressors. The concept of hindrance demands relates to negative demands that are likely to impact personal growth and trigger negative emotions, leading to distress (LePine, Podsakoff, \& LePine, 2005).

The JD-R model is a theoretical framework that integrates two independent research traditions: stress and motivation research (Demerouti \& Bakker, 2011). It was developed by Demerouti, Bakker, Nachreiner, and Schaufeli (2001). This model postulates that every occupation (or organisation) is likely to have its own work characteristics associated with well-being. The model integrates and elaborates upon previously developed job characteristics models such as the Demand Control Model (Karasek, 1979) and the Effort Reward Imbalance Model (Siegrist, 1996).

A growing interest exists to understand the positive experiences of employees, which include their optimal functioning (Luthans, 2002; Seligman \& Csikzenthmihalyi, 2000). However, in the context of this study, it is apparent that there is a need to determine the aspects of work that may hinder optimal functioning of academics in HEIs. Stressors in the workplace can reduce optimal functioning of employees. However, it should be noted that even though stressors exist in an occupation, they may not always present harmful reactions. According to Podsakoff, LePine, and LePine (2007), some stressors may potentially spur personal growth and achievement. These are referred to as challenge stressors and can be differentiated from the stressors that employees consider as constraining their personal development or work accomplishment.

Hindrance stressors influence employee turnover intention, employee loyalty, job attitudes and satisfaction (Boswell, Olson-Buchanan, \& Lepine, 2004; Podsakoff et al., 2007) as well as task performance and withdrawal behaviour (Lepine et al., 2005; Podsakoff et al., 2007). Challenge stressors consist of job or role demands, quantitative and subjective workload, time pressures and pressure to complete tasks, job scope and responsibility. Hindrance stressors consist of situational constraints, hassles, organisational politics, resource inadequacies, role ambiguity, role conflict, role overload and concerns about job security (Cavanaugh, Boswell, Roehling, \& Boudreau, 2000; Lepine et al., 2005; Podsakoff et al., 2007). 
It must be acknowledged that job demands may act as hindrance or challenge demands (Bakker \& Sanz-Vergel, 2013). The JD-R model postulates that there are job demands which may hinder employees by draining their energy. According to Tims, Bakker, and Derks (2013), prolonged exposure to work that has high job demands will deplete employees' levels of well-being. Certain demands can cause negative emotions and inhibit employees' work goals and well-being. In such instances, hindrance demands act as a barrier, preventing employees from achieving their goals (Siu, 2013).

\section{Higher Education Hindrance Demand Scale}

This study is based on the premise that hindrance demands exist and affect the work performed by academic staff. It goes beyond simply measuring whether academic staff experience work overload and goes on to include the various types of demands that cause stress. This brings to the fore the need for such an instrument to be developed and validated within a South African context.

Ideally, this measure contributes to the most recent occurrences at universities and current events in South African HEIs. The scale consists of 29 items of which 7 items capture workload, 4 items capture higher education unrest and 5 items capture each of the following: change management, decolonisation and online teaching and learning. The last dimension, psychological safety, is captured through three items. All items in the scale were measured on a sevenresponse format. This response format is in line with methodological recommendations and is regularly used in studies (Weijters, Cabooter, \& Schillewaert, 2010). A seven-point scale contains a mid-point, which ensures measurement quality (Nowlis, Kahn, \& Dhar, 2002). According to Weijters et al. (2010), a seven-response format is less problematic as it provides more categories and is best used for populations who rank high on cognitive ability.

In terms of scale development, a series of steps were followed:

- Application of a theoretical base: the parameters (variables) of the study were identified. Furthermore, Conversations, themes and forums that were common within South African institutions were discussed and decided upon to assist in the generation of items. A small group meeting led by international scholars Arnold Bakker and Eva Demerouti initiated discussion on the items of hindrance demands to be included in the scale.

- Item generation: statements were generated through inductive and deductive approaches. The deductive approach followed the review of literature (Hinkin, 1995). The inductive approach involved reviewing qualitative information on the construct through exploratory research methodologies (Kapuścinski \& Masters, 2010).

- Measurement format and item development: experts were approached to comment on the appropriateness, relevance and suitability of the questions. This allowed suggestions to be made on the structure of the questionnaire (Saunders, Lewis, \& Thornhill, 2009). The aim of pre-testing was to determine the strengths and weaknesses (format, wording and order of questions) of the questionnaire before using it for data collection.

- Conduct an item analysis to eliminate inadequate items: an expert panel of 10 academics reviewed the scale and were asked to rate the items in terms of adequacy, relevance and structure, to provide feedback on the language with regard to confusing wording or items and to suggest recommendations.

- Design and conducting developmental study: the retained items were administered to the appropriate sample with the objective of examining how well those items confirmed expectations regarding the psychometric properties (Hinkin, Tracey, \& Enz, 1997). The survey was thus administered to academics in HEIs in South Africa.

In this study, the following dimensions can be considered as a hindrance demand and have been delineated as items measured on the HEHDS.

The scales were developed based on the unique nature of HEIs in South Africa and its associated challenges faced at the time of development of the scale. Notably, there are dimensions from existing scales which were adapted from the JD-R scale, namely, workload. Although the JD-R scale exists, the dimensions are not unique to higher education. The intention of developing such a scale was not to create many items or even a lengthy questionnaire. The HEHDS is seen as a brief measure and we acknowledge that brief measures have certain psychometric limitations (Widaman, Liitle, Preacher, \& Sawalani, 2011). The nature of the scale is meant to be narrow. We acknowledge that there are a few items in the scale, however, where there is a possibility that higher order factors could exist.

\section{Work overload}

In terms of occupational stress, the concept of workload relates to job demands that may result in or contribute to the development of stress or injury. This is characterised as a psychosocial hazard (MacDonald, 2003). It is noted that the job demands of academic staff are ascribed to various factors, one of which is work overload (Barkhuizen \& Rothmann, 2008). Working long hours and the intensification of work have become a common factor in the modern-day workplace (Sang, Powell, Finkel, \& Richards, 2015). A frequent occurrence amongst academic staff is the blurring of boundaries between work and home (Wright, Williamson, Schauder, \& Stockfeld, 2003). Similar patterns of work have been observed internationally (Bagilhole \& White, 2013). The work environment of universities has changed over the last decade and the work performed by academics has been altered from secure and autonomous to insecure and invisible (May, Strachan, \& Peetz, 2013). This has resulted in significant changes in the working conditions of academia 
(Rainnie, Goods, Barns, \& Burgess, 2013). Hence, it is critical to assume that workload has the likelihood to hinder academic work.

Workload was measured by seven items on a seven-response format, which ranged from $1=$ strongly disagree to $7=$ strongly agree, and $1=$ never to $7=$ always. An example of an item in this dimension is 'I work under time pressure'. The items in this dimension were adapted from the workload scale of Rothmann and Jordaan (2006), which scored an acceptable alpha of 0.76 , and the workload dimension of Roberts, Lapidus, and Chonko (1997), which scored an acceptable alpha of 0.82 .

\section{Higher education unrest}

Several manifestations of student protests have occurred over recent years, particularly from 2015 to 2017. These acted as a mechanism for students to have their voices and concerns raised on decisions made by their institutions (Kamsteeg, 2016). South African HEIs were marred by multiple student protests, such as the 'Rhodes Must Fall' campaign and the 'Fees Must Fall' campaign (Dell, 2015; Rantao, 2015). Such unrest caused major damage to institutions, namely, disruption of the academic calendar and revision of exam dates (Pijoos, 2016), damage to buildings and disruption of examinations (Petersen, 2016). Public HEIs across South Africa were subjected to unrest and violence (Hall, 2016), where artwork, statues and buildings were damaged. Hall (2016) further states that this brought about brutal clashes and confrontations between the police and student factions.

In light of the 'Fees must fall' campaign, tuition fee increases had significant implications for higher education access. At the increases of fees, students protested, at times violently, arguing that high fees make education inaccessible to poor students (Wangenge-Ouma, 2012). In light of these incidents, it is likely that university employees, their work and entrance into the institution were impacted. Based on the aforementioned literature, it was deemed necessary to measure unrest in HEIs in South Africa. In terms of the measurement, unrest pertains to any disruption that takes place at HEIs, as we live in a time fuelled with unrest.

Higher education unrest was measured with four items on a seven-response format, which ranged from $1=$ never to 7 = always. An example of an item in this dimension is 'Due to student protests, my work was negatively affected'.

\section{Change management}

The concept of change affects all facets of society, bringing about uncertainty and creating new possibilities of how to manage changes (Bowin, 2001). Similarly, organisations function in environments that are continuously changing, which presents both risks and opportunities. It could be argued that the introduction of certain changes is essential for the survival of an organisation. However, there are instances in which change, if not managed effectively, will result in the failure of an organisation (Govender \& Rampersad, 2016).

South African HEIs were reconfigured in 2001, resulting in institutional restructuring to meet the needs of a developing democracy and paving the way for a new higher education landscape. In this regard, HEI systems were challenged by policy issues (Badat, 2009), mergers of technikons and universities, equity, access and quality (Le Grange, 2011).

According to Vandeyar (2010), HEIs are inherently resistant to change because of global pressures and international competitiveness. In light of the changes that occur within tertiary institutions, changes such as mergers can result in flagging staff morale, job insecurity and redeployment (Seijts \& Farrell, 2003). In addition, Seijts and Farrell (2003) suggest that if change is not perceived as a means of creating positive outcomes, employees are likely to resist such initiatives. In terms of higher education literature, the work duties of an academic have been transformed in terms of work tasks and conditions of employment (Enders \& Teichler, 1997; Schuster \& Finkelstein, 2008).

Higher education institutions are prone to increased levels of uncertainty from societal change because of the production of knowledge (Barnett, 2000). In addition, academics have come to work under a 'managerial paradigm' which affects the way they work and in which they are managed (Barnett, 2012). Gill (2014) notes that essential changes in work at HEIs fail to sufficiently document the experiences of employees. Notably, changes that take place are likely to affect the way in which academics perform their work.

Change management was measured through seven items on a seven-response format, which ranged from $1=$ never to 7 = always. An example of an item in this dimension is 'There are continuous changes in processes and procedures which impact my job'.

\section{Decolonisation}

A series of protest campaigns to 'decolonise' academia commenced around 2015 at universities throughout South Africa (Wamai, 2016). Decolonisation refers to addressing the colonial legacy (knowledge, violence and thought) (Pillay, 2015), which is still entrenched within education in South African HEIs (Heleta, 2016), and is perceived as a response to first- and second-generation colonialism (Le Grange, 2016).

Critical changes to the curricula in HEIs have not taken place for nearly a century, and they remain significantly unchanged despite the monumental shifts in the political landscape (Ramrathan, 2016). Such changes include moving away from colonial influences (Heleta, 2016). In terms of transformation, HEIs should include changes in the curriculum and epistemology as well as teaching and 
learning (Du Preez, Simmonds, \& Verhoef, 2016). According to McKaiser (2016), HEIs in South Africa remain entrenched in a colonial outpost mentality and the few changes that have occurred have been superficial and were initiated through the response of policies, namely, professional bodies, qualification frameworks and curriculum frameworks (Ramrathan, 2016). Moreover, Mbembe (2016) indicates that syllabi are designed in a manner to meet the needs of colonialism; hence, it is important to bring about significant epistemological changes in HEIs. Although universities have developed policies and frameworks on change, transformation, equality and equity, they have still not progressively changed (Heleta, 2016).

The debate around the decolonisation of the curriculum is positioned within the context of universities that are strained from various quarters, notably, lack of government funding, increased running costs and increased student access, which makes time-intensive learning processes all the more expensive and unwelcome from a managerial perspective (Kamanzi, 2016). In order for the scholarship of academia and the curriculum to become decolonised, HEIs need to address matters by finding leaders, academics and administrators who possess knowledge of and passion for African content. Because of the past political landscape, white academics were out of touch with such knowledge (Mkhize, 2015). The recent initiation of decolonisation in HEIs may have an impact on academics and their work. With its continuation and universities prioritising decolonising imperatives, it is essential to see the way in which it is being perceived by academics.

Decolonisation was measured by five items on a sevenresponse format, which ranged from $1=$ strongly disagree to 7 = strongly agree. An example of an item on this dimension is 'Decolonisation of higher education will bring about changes in the way in which I approach my work'.

\section{Online teaching and learning}

Fundamental changes in higher education have shifted the role of academics as they become increasingly involved in the changing nature of teaching, namely, online education (Bennett \& Lockyer, 2004). The reform of teaching and learning has occurred through the use of technology which has highlighted change and transformation (Strobel \& Tillberg-Webb, 2008). The proliferation of online technologies in higher education has resulted in transformation for students and teachers (Collis, 1996; Palloff \& Pratt, 1999). The vast differences between traditional teaching and online teaching bring about advantages and disadvantages (Oliver \& Herrington, 2001).

According to Allen and Seaman (2013), faculty staff members are increasingly prone to resisting online learning. They resist online teaching and learning as they perceive that educational values and culture are being threatened
(Bennett \& Lockyer, 2004). Concerns that arise from online teaching and learning include an increase in workload, lack of resources and technological skills and training as well as pedagogical concerns (Bennett \& Lockyer, 2004; Hunt et al., 2014; Johnson, Wisniewski, Kuhlemeyer, Isaacs, \& Krzykowski, 2012; Power \& Gould-Morven, 2011). These concerns are also heightened amongst faculty members who have little or no experience with online teaching (Herman, 2012). Such academics cite fear and resist change to online learning. Some senior academics prefer to hold on to traditional face-to-face teaching (Goolnik, 2012). Academics may perceive that they are being challenged and are inadequately skilled to utilise technologically based teaching and learning tools. With online teaching and learning becoming a reality in HEIs, it is essential to establish whether it is considered a hindrance.

Online teaching and learning was measured by five items on a seven-response format, which ranged from 1 = strongly disagree to $7=$ strongly agree. An example of an item on this dimension is 'The drive towards online teaching and learning in my department is progressing well'.

\section{Psychological safety}

Early research by Kahn (1990) refers to psychological safety as one's ability to apply and show the fear of consequences towards one's career, self-image and status. In more recent research, Edmondson and Lei (2014) explain that psychological safety refers to the feeling of safety whereby people are able to perform effectively in a rapidly changing world under the circumstances of growing and learning. Psychological safety assists people in overcoming barriers to change and learning and work environments that are interpersonally challenging (Edmondson, Higgins, Singer, \& Weiner, 2016).

Edmondson, Bohmer, and Pisano (2001) assert that psychological safety is particularly important in environments that are characterised by complexity, high stakes and essential human interactions. There is a likelihood that individuals feel safe in environments where they are able to express themselves without fear of reprisal, being victimised or penalised. When conditions are perceived by individuals as unpredictable and ambiguous, a lack of psychological safety may be experienced (Chikoko, Buitendach, \& Kanengoni, 2014).

Psychological safety influences the way in which an individual engages with his or her work. Factors that affect psychological safety are behavioural norms, supervisory relations and relationships between co-workers (Kahn, 1990). Edmondson (1999) notes that psychological safety varies amongst organisations and workgroups.

Academic staff in HEIs face challenges in their daily work that may lesson their sense of psychological safety. A climate may exist within the organisation, which may impact the psychological safety of staff members. The concept of 
psychological safety asserts itself with elements that allow for consistent social systems that are non-threatening and predictable to be created. This allows social situations to prevail and, hence, allows for engagement (Kahn, 1990). Therefore, it is imperative to assess the psychological safety of academics.

Psychological safety was drawn from Kahn (1990) and included three items on a seven-response format, where 7 = strongly agree, and $1=$ never and $7=$ always. An example of an item on this dimension is 'I am afraid to be myself at work'. Olivier and Rothmann (2007) reported an acceptable Cronbach's alpha coefficient of 0.71 .

\section{Method}

\section{Research design, setting and respondents}

A non-probability sampling method was utilised and through a convenience sample data were collected from academics across universities in South Africa. Questionnaires were completed online; in total, 184 responses were received from academic staff. The size of a sample is deemed essential for factor analysis and varying guidelines exist in this regard (Tabachnick \& Fidell, 2007; Williams, Onsman, \& Brown, 2010). Hair, Anderson, Tatham, and Black (1995) and Comrey (1973) suggest that a sample size of 100 participants is considered sufficient and fair. It is noted that the sample size is small for factor analysis. This, however, does not invalidate the results and, hence, should be interpreted with caution.

The majority of the sample comprised women (56\%) and men accounted for $44 \%$. The participants comprised academic staff, with the majority of them employed as lecturers (40.8\%), followed by senior lecturers (27.2\%), associate professors and professors (19.6\%), heads of departments/schools $(5.4 \%)$, junior lecturers $(2.2 \%)$, other $(3.8 \%)$ and researchers $(1.1 \%)$. The white race group $(52.3 \%)$ was the most represented in the sample. The majority of the population had a master's degree (31\%). A high proportion of employees were permanently employed $(90.8 \%)$ by their institutions in comparison to staff members who held temporary positions (2.2\%). In terms of tenure, staff members had been employed at the HEIs for $0-5$ years $(28.8 \%)$, followed by $6-10$ years $(24.5 \%), 11-20$ years $(21.7 \%)$ and greater than 20 years $(12.5 \%)$. The average age of employees was 43 years $(S D=10.48$ years), and ranged between 23 and 67 years. It must be noted that $91.8 \%$ of the population was representative of the Faculty of Commerce.

\section{Data analyses}

Statistical analysis was carried out using $\mathrm{R}$ Studio 3.2.0 (R Development Core Team, 2015). Descriptive statistics were obtained for all factors on the hindrance demands scale and the data were analysed in terms of mean, standard deviation, skewness, kurtosis and Cronbach's alpha coefficient of each item. The current study utilised exploratory factor analysis to examine construct validity of the HEHDS. To determine the suitability of the factor structure, the Kaiser-Meyer-Olkin (KMO) measure of sampling adequacy and Bartlett's test of sphericity (Burton \& Mazerolle, 2011; Pallant, 2011) were analysed. With this analysis, the bootstrap function was conducted with 1000 iterations. This function allows for the construction of confidence intervals (Kim, Kim, \& Schmidt, 2007). It is valuable in estimating biases and variances and constructs confidence intervals in complex data sets (Ichikawa \& Konishi, 1995).

In terms of $\mathrm{KMO}$, the index ranged from 0 to 1 , and a recommended value of 0.6 and above is considered suitable (Pallant, 2011). Items that are grouped into a set of interpretable factors can efficiently explain the constructs under investigation (Burton \& Mazerolle, 2011). Bartlett's test of sphericity provides a chi-square output which should be significant at $<0.05$ as recommended by Pallant (2011).

The study used unweighted least-squares method (minimum residual - MinRes) as the factor extraction method. To determine model fit, absolute and incremental fit indices were determined. The absolute fit indices for this study were the following: chi-square $\left(\chi^{2}\right)$, fit statistic, the standardised root mean residual (SRMR) and the root mean square error of approximation (RMSEA). The assessment of incremental fit indices included the Tucker-Lewis Index (TLI) (Hair, Black, Babin, Andersen, \& Tatham, 2010). The study utilised the rule of thumb whereby an RMSEA $\leq 0.05$ indicates close approximate fit, values between 0.05 and 0.08 indicate reasonable error of approximation and an RMSEA $\geq 0.10$ suggests a poor fit (Kline, 2005). In terms of the indices, if the TLI value is greater than roughly 0.90 , this may suggest a reasonably good fit of the model, whereas values less than 0.10 are considered favourable. Consequently, the model with the largest TLI as well as the lowest RMSEA and SRMR is considered the best fit. The TLI can substantially improve models with an overall fit of less than 0.90 (Bentler \& Bonett, 1980). The comparative fit index, namely, Bayesian information criterion (BIC), is indicative of model parsimony (Kline, 2011).

\section{Results}

The initial examination of the HEHDS used Kaiser-Guttman's criterion, while Cartell's scree plot was used to determine the number of factors to be extracted. The KMO measure of sampling adequacy for the hindrance demands scale, which contained 29 items in the first iteration, was 0.8 . This exceeded the recommended value of 0.6 (Tabachnick \& Fidell, 2007). It is notable that normality and homoscedasticity preconditions for the study were fulfilled. The scree plot indicated that the five factors should be retained; however, the parallel analysis suggested six factors and six components. Hence, both models were tested to determine the number of factors to be extracted and to determine model fits. In this analysis, the bootstrap function was conducted with 100 iterations. The bootstrap function allows for the construction of confidence intervals (Kim et al., 2007). 
TABLE 1: Dimensionality analysis of the five-factor and six-factor models.

\begin{tabular}{lccccccc}
\hline Model & $\chi^{2}$ & $d f$ & TLI & RMSEA & SRMR & 90\% intervals & BIC \\
\hline Model 1 & 2363.29 & 271 & 0.755 & 0.079 & 0.05 & 0.0690 .083 & -829.35 \\
Model 2 & 2363.29 & 247 & 0.848 & 0.062 & 0.04 & 0.050 .067 & -865.17 \\
\hline
\end{tabular}

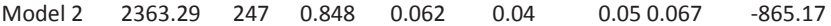

$d f$, degrees of freedom; TLI, Tucker-Lewis Index; RMSEA, root mean square error of approximation; SRMR, standardised root mean square residual; BIC, Bayes information criterion.

The fits of the five- and six-factor models were then compared (see Table 1). Model 1 represents the five-factor solution with items loading freely on the five factors, while Model 2 is the six-factor solution with items loading freely on the six factors (as hypothesised). The fit indices of both models were satisfactory.

From the examination of the chi-square fit statistics for Model $1(p<0.000)$ and Model $2(p<0.000)$, it was inferred that Model 2 had a better fit. The TLI values were regarded as satisfactory for both the five-factor (0.755) and the six-factor (0.848) models. Reasonable error of approximation was indicated with regard to RMSEA for Model 1 (0.0790) and Model 2 (.062). Based on the squared mean square residual (SMSR), both models provided favourable results (Model $1=0.05$ and Model $2=0.04$ ), which were lower than the suggested cut-off point of $<0.10$. The BIC value suggested that the five-factor model $(-829.350)$ has a better fit than the six-factor model (-865.17) and, hence, allowed for differentiation between the competing models. In addition, $90 \%$ intervals were reported. Based on the aforementioned results, Model 2 has a suitable fit and factor structure.

The 29 items of the six-factor model of the HEHDS were subjected to a factor analysis using unweighted least square method (minimum residual - MinRes) and a direct oblimin rotation. Upon inspection of the analysis, the factor loadings that remained were undefined and unstructured. Hence, an uncorrelated factor solution was tested and the results indicated that the data best fitted an uncorrelated factor solution

\section{Factor solutions}

Based on the statistical fit presented in Table 1, it was suggested that the six-factor analysis should be further inspected to facilitate the interpretation of the models and, hence, the respective factor solutions were examined. Solutions that presented two or more factors could have different factor structures and hence explain the data equally well. Factor loadings that were below the cut-off point of 0.30 were interpreted as non-significant (Diekhoff, 1992) and were not considered during the examination of the factor matrix. The standardised factor loadings for the six-factor solution indicated that the items DECO2, DECO1, OTL1 and OTL4 were to be removed as they did not load against any factors and were considered non-interpretative, which also scored low communalities between 0.14 and 0.23 (see Table 2). In addition, the items CHMAN 1, CHMAN5 and CHMAN4 loaded on more than one factor. These were considered problematic and were hence removed.
TABLE 2: Factor loadings for the six-factor model of 29 items - first iteration.

\begin{tabular}{|c|c|c|c|c|c|c|c|c|}
\hline Item & F1 & F2 & F3 & F4 & F5 & F6 & $h^{2}$ & $\mathbf{u}^{2}$ \\
\hline HEU4 & 0.86 & 0.08 & 0.00 & 0.10 & -0.10 & 0.03 & 0.77 & 0.23 \\
\hline HEU1 & 0.83 & 0.06 & 0.05 & 0.09 & -0.09 & -0.03 & 0.71 & 0.29 \\
\hline HEU3 & 0.82 & 0.10 & 0.07 & 0.06 & -0.05 & 0.04 & 0.70 & 0.30 \\
\hline HEU2 & 0.76 & 0.08 & -0.04 & 0.07 & -0.03 & -0.02 & 0.59 & 0.41 \\
\hline DECO2 & 0.32 & 0.25 & 0.04 & 0.15 & 0.02 & 0.25 & 0.25 & 0.75 \\
\hline PSAF2 & 0.05 & 0.77 & 0.13 & 0.05 & -0.16 & 0.05 & 0.65 & 0.35 \\
\hline PSAF3 & 0.06 & 0.72 & 0.10 & 0.21 & -0.20 & -0.02 & 0.62 & 0.38 \\
\hline PSAF1 & 0.13 & 0.70 & 0.12 & 0.05 & -0.21 & 0.04 & 0.57 & 0.43 \\
\hline CHMAN5 & 0.18 & 0.47 & 0.04 & 0.42 & -0.07 & 0.21 & 0.48 & 0.52 \\
\hline CHMAN4 & 0.18 & 0.46 & 0.01 & 0.49 & 0.01 & 0.20 & 0.52 & 0.48 \\
\hline CHMAN1 & 0.29 & 0.45 & -0.01 & 0.42 & 0.08 & 0.10 & 0.49 & 0.51 \\
\hline WL1 & -0.05 & -0.09 & 0.77 & 0.06 & -0.01 & 0.03 & 0.61 & 0.39 \\
\hline WL5 & 0.10 & -0.08 & 0.67 & -0.02 & 0.03 & 0.11 & 0.47 & 0.53 \\
\hline WL4 & 0.02 & 0.21 & 0.62 & 0.09 & -0.07 & 0.04 & 0.45 & 0.55 \\
\hline WL3 & 0.11 & 0.12 & 0.48 & -0.07 & -0.18 & 0.15 & 0.32 & 0.68 \\
\hline WL2 & 0.01 & 0.00 & 0.45 & 0.16 & 0.06 & 0.00 & 0.23 & 0.77 \\
\hline WL6 & -0.02 & 0.08 & 0.44 & 0.05 & -0.03 & 0.13 & 0.22 & 0.78 \\
\hline WL7 & -0.06 & 0.21 & 0.39 & 0.21 & 0.02 & 0.00 & 0.24 & 0.76 \\
\hline CHMAN3 & 0.04 & 0.23 & 0.14 & 0.77 & -0.10 & 0.06 & 0.68 & 0.32 \\
\hline CHMAN2 & 0.02 & 0.24 & 0.13 & 0.74 & -0.06 & 0.10 & 0.63 & 0.37 \\
\hline DECO1 & 0.13 & -0.09 & 0.10 & 0.33 & 0.00 & 0.07 & 0.15 & 0.85 \\
\hline DECO5 & -0.06 & -0.11 & -0.07 & -0.02 & 0.89 & -0.02 & 0.81 & 0.19 \\
\hline DECO4 & -0.03 & -0.15 & -0.03 & -0.01 & 0.85 & 0.09 & 0.76 & 0.24 \\
\hline DECO3 & -0.22 & -0.06 & -0.07 & -0.18 & 0.42 & -0.10 & 0.28 & 0.72 \\
\hline OTL1 & 0.01 & -0.18 & 0.06 & 0.03 & 0.27 & -0.12 & 0.13 & 0.87 \\
\hline OTL5 & 0.12 & 0.22 & 0.03 & 0.07 & 0.08 & 0.76 & 0.65 & 0.35 \\
\hline OTL3 & 0.04 & 0.29 & 0.13 & 0.07 & -0.04 & 0.75 & 0.68 & 0.32 \\
\hline OTL2 & 0.02 & -0.10 & 0.21 & 0.30 & -0.05 & 0.62 & 0.54 & 0.46 \\
\hline OTL4 & 0.09 & 0.13 & -0.14 & -0.03 & 0.14 & -0.41 & 0.23 & 0.77 \\
\hline
\end{tabular}

WL, workload; HEU, higher education unrest; CHMAN, change management; DECO, decolonisation; OTL, online teaching and learning; PSAF, psychological safety.

The remaining factor loadings for this solution ranged between 0.36 and 0.88 , which is indicative of fairly strong to very strong factor loadings. The communalities ranged between 0.20 and 0.80 . Evidently, the majority of the values fell above the cut-off point of $>0.40$. Furthermore, the solution provided six clearly defined sub-clusters, thus providing significant support for the six-factor model.

A second iteration of factor analysis was conducted using the unweighted least-squares method (MinRes). All items loaded accordingly on six factors and the factor loadings ranged from 0.31 to 0.89 , with communalities ranging between 0.19 and 0.88 . The item CHMAN1 loaded on more than one factor and hence it was decided to remove the factor and conduct the third iteration of the factor analysis.

The third iteration of the factor analysis was conducted (see Table 3) using the unweighted least-squares method (MinRes) and the respective solutions were examined. The factor solutions presented different factor structures and explained the data well. The second iteration data, CHMAN1, were removed. The standardised pattern matrix containing the factor loadings for the revised six-factor solution is indicated in Table 4. All of the factor loadings fell above the suggested cut-off point of 0.30 and ranged from 0.35 to 0.90 , which is indicative of fairly strong to very high factor loadings. Communalities for the final structure ranged between 0.19 and 0.88 , with the majority of the values falling 
TABLE 3: Factor loadings for the final six-factor model of 22 items.

\begin{tabular}{|c|c|c|c|c|c|c|c|c|}
\hline Item & F1 & F2 & F3 & F4 & F5 & F6 & $h^{2}$ & $u^{2}$ \\
\hline HEU4 & 0.89 & -0.01 & 0.09 & -0.08 & 0.06 & 0.07 & 0.81 & 0.19 \\
\hline HEU1 & 0.85 & 0.05 & 0.06 & -0.08 & 0.01 & 0.06 & 0.74 & 0.27 \\
\hline HEU3 & 0.81 & 0.08 & 0.08 & -0.06 & 0.06 & 0.01 & 0.68 & 0.32 \\
\hline HEU2 & 0.75 & -0.04 & 0.06 & -0.06 & 0.03 & 0.03 & 0.57 & 0.43 \\
\hline WL1 & -0.06 & 0.77 & -0.08 & -0.05 & 0.02 & 0.03 & 0.61 & 0.39 \\
\hline WL5 & 0.08 & 0.68 & -0.09 & -0.01 & 0.09 & -0.05 & 0.49 & 0.51 \\
\hline WL4 & 0.03 & 0.62 & 0.24 & -0.06 & 0.04 & 0.07 & 0.45 & 0.55 \\
\hline WL3 & 0.11 & 0.48 & 0.15 & -0.15 & 0.14 & -0.07 & 0.31 & 0.69 \\
\hline WL2 & 0.02 & 0.46 & -0.01 & 0.06 & 0.00 & 0.16 & 0.24 & 0.76 \\
\hline WL6 & -0.02 & 0.44 & 0.08 & -0.03 & 0.12 & 0.06 & 0.22 & 0.78 \\
\hline WL7 & -0.05 & 0.38 & 0.19 & 0.00 & 0.04 & 0.21 & 0.23 & 0.77 \\
\hline PSAF2 & 0.07 & 0.10 & 0.86 & -0.09 & 0.09 & 0.10 & 0.78 & 0.22 \\
\hline PSAF1 & 0.13 & 0.10 & 0.71 & -0.19 & 0.10 & 0.07 & 0.58 & 0.42 \\
\hline PSAF3 & 0.09 & 0.08 & 0.70 & -0.16 & 0.04 & 0.26 & 0.60 & 0.40 \\
\hline DECO4 & -0.01 & -0.01 & -0.17 & 0.94 & 0.07 & 0.01 & 0.91 & 0.09 \\
\hline DECO5 & -0.06 & -0.06 & -0.16 & 0.81 & -0.01 & -0.02 & 0.70 & 0.30 \\
\hline DECO3 & -0.21 & -0.08 & -0.06 & 0.44 & -0.07 & -0.14 & 0.27 & 0.73 \\
\hline OTL5 & 0.09 & 0.05 & 0.12 & 0.04 & 0.82 & 0.03 & 0.71 & 0.29 \\
\hline OTL3 & 0.03 & 0.15 & 0.19 & -0.04 & 0.82 & 0.07 & 0.74 & 0.26 \\
\hline OTL2 & 0.03 & 0.22 & -0.10 & -0.03 & 0.52 & 0.25 & 0.39 & 0.61 \\
\hline CHMAN2 & 0.07 & 0.13 & 0.19 & -0.05 & 0.15 & 0.84 & 0.79 & 0.21 \\
\hline CHMAN3 & 0.09 & 0.14 & 0.19 & -0.10 & 0.12 & 0.78 & 0.69 & 0.31 \\
\hline
\end{tabular}

WL, workload; HEU, higher education unrest; CHMAN, change management; DECO, decolonisation; OTL, online teaching and learning; PSAF, psychological safety.

TABLE 4: Dimensionality of the finalised six-factor models.

\begin{tabular}{lccccccc}
\hline Model & $\chi^{2}$ & $d f$ & TLI & RMSEA & SRMR & 90\% intervals & BIC \\
\hline Model 3 & 1825 & 231 & 0.9 & 0.06 & 0.04 & 0.050 .07 & -394
\end{tabular}

$d f$, degrees of freedom; TLI, Tucker-Lewis Index; RMSEA, root mean square error of approximation; SRMR, standardised root mean square residual; BIC, Bayes information criterion.

above the cut-off point of $>0.40$. The solution indicated six clearly defined sub-clusters, thus providing significant support for the six-factor model. The proportion of variance explained by the six factors was examined. Factor 1 accounted for $10 \%$ of the variance, while Factor 2 accounted for $20 \%$. Factors 3 and 4 of the six-factor model explained 33\% and $42 \%$ of the variance, respectively. Fifty per cent of the variance was explained by Factor 5, while 57\% was explained by Factor 6.

All the factors achieved acceptable Cronbach's alpha coefficients, ranging from 0.77 (lowest) to 0.90 (highest). Hence, the scale satisfied the requirements of internal consistency.

\section{Discussion}

The primary aim of this study was to develop the HEHDS within the South African context. The primary focus was to develop a scale to measure hindrance demands. The scale design was based on the hindrance demands apparent within the South African higher education context. The study set out to achieve a six-factor scale, which was achieved through exploratory factor analysis.

The reliability of the HEHDS was assessed using Cronbach's alpha coefficient. The overall reliability derived from the instrument was acceptable, as all alphas were above the cut-off point of 0.70 (Nunnally \& Bernstein, 1994). This is indicative of good reliability and internal consistency of the instrument. Table 3 depicts the mean, standard deviation, skewness and kurtosis for each of the final 22 items of the HEHDS. According to the descriptive statistics, there were no problematic items present with regard to skewness and kurtosis and hence the scale can be considered as normally distributed, based on the cut-off points for skewness $(<2)$ and kurtosis $(<4)$. The mean values for items ranged from 2.891 (PSAF3) to 5.641 (WL5). Normality and homoscedasticity preconditions for the study were fulfilled as the KMO was 0.80 and Bartlett's test of sphericity reached statistical significance. This indicates that the correlation matrix of the HEHDS was acceptable and supported factorability.

\section{Determining the factor structure}

Upon inspection of the parallel analysis and scree plot, it was suggested that a five-factor and a six-factor structure should be considered. Consequently, both structures were tested. However, based on the fit statistics, the six-factor structure fitted the data best and was also in line with the overall hypothesis of this study, namely, higher education unrest, workload, psychological safety, decolonisation, online teaching and learning and change management. It is not uncommon for academic work to be affected by numerous job demands, such as work overload, job insecurity, and lack of growth opportunities, which affect people in the workplace (Bakker \& Demerouti, 2007), and more specifically, different types of job demands, such as emotional demands and physical demands (Bakker \& Demerouti, 2007). Previous research further supports an expanded model of job demands and job resources which can affect stress at work (Barkhuizen, 2005; Bakker \& Demerouti, 2007; Demerouti \& Bakker, 2011).

\section{Factor rotation}

The solutions of the exploratory factor analysis for a fivefactor and a six-factor model were evaluated and compared. The goodness of fit indices and the model parameters were examined. The goodness of fit indices for both the five-factor model (TLI = 0.755; RMSEA $=0.079$; report root-mean-square residuals $[$ RMSR] $=0.05)$ and the six-factor model $($ TLI $=$ 0.848; $\mathrm{RMSR}=0.062 ; \mathrm{RMSR}=0.04)$ solutions were satisfactory. However, the five-factor model produced a lower BIC value (-829.35) than the six-factor model (-865.17). Hence, the six-factor model was deemed more suitable.

Following this, the proposed six-factor model containing the 29 items was subjected to a further iteration of exploratory factor analysis with an uncorrelated factor solution.

\section{Item fit}

The inspection of the results from the first iteration analysis of the six-factor model suggested that problematic items were present. Such items loaded on more than one factor. CHMAN5 (Changes in the leadership in my work environment make me feel unsettled about the university's future), CHMAN1 
(I feel insecure about my job due to changes in my work environment) and CHMAN4 (Changes within my work environment make me feel anxious about my job) loaded on the factors 'change management' and 'psychological safety'. It is likely that the way in which the item of change management was expressed is similar to that of psychological safety or bears resemblance to items measured under psychological safety. The overlapping factors are likely to suggest that the respective items do not provide adequate distinction or clarification for the factor upon which the double loading exists, except for CHMAN1, which loaded adequately on psychological safety. Hence, those items were considered problematic and discarded.

In addition, items DECO2 (Decolonisation of higher education makes me feel unsettled about my work) and DECO1 (Decolonisation of higher education will bring about changes in the way in which I approach my work) did not load on any factor. The concept of decolonisation is fairly new and refers to colonial legacy (knowledge, violence and thought) (Pillay, 2015) within academia in South African HEIs (Heleta, 2016). It is likely that the concept could be defined differently or perceived differently by academics and hence could possibly influence how it is measured.

OTL4 (My involvement in online teaching and learning initiatives has left me feeling anxious about my work) and OTL1 (The drive towards online teaching and learning in my department is progressing well) did not present any factor loadings and hence were discarded. It is possible that online teaching and learning may not have had a presence in the department or institution and may therefore not have been interpreted well.

The remainder of the 22 items, with the removal of items DECO2, CHMAN5, CHMAN4, DECO1, OTL5 and OTL1, attained factor loadings that ranged from 0.36 to 0.88 , while communalities ranged between 0.20 and 0.80 . This provided an insight that a further iteration of factor analysis was required and, hence, a third iteration was conducted to include 22 items to determine a finalised structure.

The fit statistics of the final 22-item scale indicated good fit and showed improvement from the original 29-item scale, which was done in the first iteration, and is indicative of a suitable structure. Hence, it can be confirmed as the final factor structure of the HEHDS which includes 22 items, still defined under the following six factors: (1) higher education unrest, (2) work load, (3) change management, (4) decolonisation, (5) online teaching and learning and (6) psychological safety.

\section{Limitations and recommendations for future research}

It should be noted that scientific research is rarely without limitations. This study has several limitations which need to be addressed. Limitations included that the data were based on a convenience sample and did not utilise probability sampling. The study was conducted on a limited number of HEIs in South Africa because of accessibility and convenience. A number of other universities in South Africa could be considered for future research.

A subsequent limitation of the study was the number of participants. A larger sample size could yield more robust results. We acknowledge that the sample size was small and thus the results of the study should be interpreted with caution. A final limitation regarding the sample was that the majority of participants were from the Faculty of Commerce. It is possible that other disciplines within HEIs could experience hindrances differently. Future research could use the scale and consider validating it through the use of confirmatory factor analysis (CFA).

The items may seem narrow, and it is duly recommended that future studies build upon these items. Future studies can use the scale as a base and as development continues, add to it. It is acknowledged that more items can be added to the scale in the future.

There is a need for further research to be conducted on the challenges that exist within HEIs (Mouton, Louw, \& Strijdom, 2012). Such studies could establish which of the demands in the present study could be differentiated as either a challenge or a hindrance demand, and could possibly add to the demands that are experienced by academic staff that are unique to the institution. The study contributed towards literature by investigating the perceived demands that challenge work within a specific occupational group, namely, academics.

\section{Conclusion}

The study developed a scale to measure hindrance demands within HEIs in a South African context. The study assessed the relationship between the six dimensions of the HEHDS which was established as reliable and valid for the South African context. In addition, the study contributed to the limited body of knowledge on hindrance demands within a higher education setting.

Furthermore, the study expanded the JD-R theory by integrating it with the hindrance stressor framework (Cavanaugh et al., 2000; LePine et al., 2005). Hindrance demands are likely to place strain on employee work; however, they do not necessarily increase strain and may be considered as a challenge demand. The scale developed in this study will be useful to researchers in higher education, heads of department and executive deans to better understand the demands placed upon academic staff. Although there is literature on the JD-R model, there is only limited information on the hindrance demands of academics within a higher education setting. Exposure to such demands is likely to leave employees feeling unsettled, and it may alter their engagement levels and diminish the meaning they find in their work. It is recommended that human resource 
practitioners establish strategies to mitigate the feelings caused by hindrance demands and that such demands remain on high alert on the agenda of academics who are within the management echelons of HEIs.

This study makes a unique contribution to the literature by integrating the hindrance stressor framework of academics based on the JD-R model and revealing the different hindrance demands affecting academics within the unique South African landscape. The HEHDS builds upon the notion that it may serve as a good first step in stimulating research on hindrance or even challenge demands of academics in South Africa.

\section{Acknowledgements Competing interests}

The authors declare that they have no financial or personal relationship(s) which may have inappropriately influenced them in writing this article.

\section{Author's contributions}

N.D., R.D.B. and M.G. co-designed the research study. N.D. conducted the research and was the main writer of the manuscript. R.D.B. and M.G. assisted with data analysis and contributed to the writing of the manuscript.

\section{References}

Allen, I. E., \& Seaman, J. (2013). Changing course: Ten years of tracking online education in the United States. Newburyport: Sloan Consortium.

Altbach, P. G., Reisberg, L., \& Rumbley, L. E. (2010). Tracking a global academic revolution: Change. The Magazine of Higher Learning, 42(2), 30-39. https://doi. org/10.1080/00091381003590845

Anderson, D., Richard, J., \& Saha, L. (2002). Changes in academic work: implications for universities of the changing age distribution and work roles of academic staff. Canberra: Department of Education, Science and Training.

Arnold, C. A., Stofile, R. N., \& Lillah, R. (2013). Assessing the outcomes of the higher education mergers in South Africa: Implications for strategic management, Acto Commercii, 13(1), 1-11. https://doi.org/10.4102/ac.v13i1.175

Badat, S. (2009). Theorising institutional change: Post-1994 South African higher education. Studies in Higher Education, 34(4), 455-467. https://doi.org/10.1080/ 03075070902772026

Badat, S. (2010). The challenges of transformation in higher education and training institutions in South Africa. Development Bank of Southern Africa, 8, 1-37.

Bagilhole, B., \& White, K. (Eds.). (2013). Generation and gender in academia. New York: Springer.

Bakker, A. B., \& Demerouti, E. (2007). The job demands-resources model: State of the art. Journal of Managerial Psychology, 22(3), 309-328. https://doi.org/ the art. Journal of Managerial
$10.1108 / 02683940710733115$

Bakker, A. B., \& Sanz-Vergel, A. I. (2013). Weekly work engagement and flourishing: The role of hindrance and challenge job demands. Journal of Vocational Behavior 83(3), 397-409. https://doi.org/10.1016/j.jvb.2013.06.008

Barkhuizen, E. N. (2005). Work wellness of academic staff in South African higher education institutions. Retrieved from http://nrfnexus.nrf.ac.za/handle/20.500. $11892 / 42$.

Barkhuizen, E. N., Roodt, E., \& Schutte, N. (2014). Talent management of academics: Balancing job demands and job resources. Mediterranean Journal of Socia Sciences, 5(20), 2033. https://doi.org/10.5901/mjss.2014.v5n20p2033

Barkhuizen, E. N., \& Rothmann, S. (2008). Occupational stress of academic staff in South African higher education institutions. South African Journal of Psychology, 38(2), 321-336. https://doi.org/10.1177/008124630803800205

Barkhuizen, E. N., Rothmann, S., \& Van de Vijver, F. J. (2014). Burnout and work engagement of academics in higher education institutions: Effects of dispositional optimism. Stress and Health, 30(4), 322-332. https://doi.org/10.1002/smi.2520

Barnett, R. (2000). Supercomplexity and the curriculum. Studies in Higher Education, 25(3), 255-265. https://doi.org/10.1080/713696156

Barnett, R. (2012). Learning for an unknown future. Higher Education Research \& Development, 31(1), 65-77. https://doi.org/10.1080/07294360.2012.642841
Bellamy, S., Morley, C., \& Watty, K. (2003). Why business academics remain in Australian universities despite deteriorating working conditions and reduced job satisfaction: An intellectual puzzle. Journal of Higher Education Policy and Management, 25(1), 13-28. https://doi.org/10.1080/13600800305740

Bennett, S., \& Lockyer, L. (2004). Becoming an online teacher: Adapting to a changed environment for teaching and learning in higher education. Educational Media International, 41(3), 231-248. https://doi.org/10.1080/09523980410001680842

Bentler, P. M., \& Bonett, D. G. (1980). Significance tests and goodness of fit in the analysis of covariance structures. Psychological Bulletin, 88(3), 588. https://doi. org/10.1037/0033-2909.88.3.588

Bezuidenhout, A., \& Cilliers, F. V. (2010). Burnout, work engagement and sense of coherence in female academics in higher-education institutions in South Africa. SA Journal of Industrial Psychology, 36(1), 1-10. https://doi.org/10.4102/sajip. v36i1.872

Boswell, W. R., Olson-Buchanan, J. B., \& LePine, M. A. (2004). Relations between stress and work outcomes: The role of felt challenge, job control and psychological strain. Journal of Vocational Behavior, 64(1), 165-181. https://doi.org/10.1016/ S0001-8791(03)00049-6

Bowin, R. B. (2001). Human resource management: An experiential approach (2nd edn.) Upper Saddle River, NJ: Prentice-Hall.

Burton, L. J., \& Mazerolle, S. M. (2011). Survey instrument validity part I: Principles of survey instrument development and validation in athletic training education research. Athletic Training Education Journal, 6(1), 27-35.

Cavanaugh, M. A., Boswell, W. R., Roehling, M. V., \& Boudreau, J. W. (2000). An empirical examination of self-reported work stress among US managers. Journa of Applied Psychology, 85(1), 65. https://doi.org/10.1037/0021-9010.85.1.65

Chikoko, G. L., Buitendach, J. H., \& Kanengoni, H. (2014). The psychological conditions that predict work engagement among tertiary education employees. Journal of Psychology in Africa, 24(6), 469-474. https://doi.org/10.1080/14330 237.2014.997026

Coetzee, S. E., \& Rothmann, S. (2005). Work engagement of employees at a higher education institution in South Africa. Southern African Business Review, 9(3), 23-34.

Collis, B. (1996). The Internet as an educational innovation: Lessons from experience with computer implementation. Educational Technology, 36(6), 21-30.

Comrey, A. L. (1973). A first course in factor analysis. New York: Academic Press.

Debowski, S. 2007. Challenges and dilemmas for Australian academics. HERDSA News, 29(3), 21.

Dell, S. (2015). Government freezes fees as student protests mount. University World News. Retrieved from http://www.universityworldnews.com/article.php?story= 2015102511561443

Demerouti, E., \& Bakker, A. B., 2011. The job demands-resources model: Challenges for future research. SA Journal of Industrial Psychology, 37(2), 1-9. https://doi. org/10.1037/0021-9010.86.3.499

Demerouti, E, Bakker, A. B., Nachreiner, F, \& Schaufeli, W. B. (2001). The job demandsresources model of burnout. Journal of Applied Psychology, 86(3), 499-512.

Diekhoff, G. (1992). Statistics for the social and behavioral sciences. Dubuque, IA: Wm. C. Brown.

Du Preez, P., Simmonds, S., \& Verhoef, A. H. (2016). Rethinking and researching transformation in higher education: A meta-study of South African trends. Transformation in Higher Education, 1(1), 1-7. https://doi.org/10.4102/the.v1i1.2

Edmondson, A. C. (1999). Psychological safety and learning behavior in work teams. Administrative Science Quarterly, 44(2), 350-383. https://doi.org/10.2307/ 2666999

Edmondson, A. C., Bohmer, R. M., \& Pisano, G. P. (2001). Disrupted routines: Team learning and new technology implementation in hospitals. Administrative Science Quarterly, 46(4), 685-716. https://doi.org/10.2307/3094828

Edmondson, A. C., Higgins, M., Singer, S., \& Weiner, J. (2016). Understanding psychological safety in health care and education organizations: A comparative perspective. Research in Human Development, 13(1), 65-83. https://doi.org/10.1 080/15427609.2016.1141280

Edmondson, A. C., \& Lei, Z. (2014). Psychological safety: The history, renaissance and future of an interpersonal construct. Annual Review of Organizational Psychology and Organizational Behavior, 1(1), 23-43. https://doi.org/10.1146/annurevorgpsych-031413-091305

Enders, J., \& Teichler, U. (1997). A victim of their own success? Employment and working conditions of academic staff in comparative perspective. Higher Education, 34(3), 347-372. https://doi.org/10.1023/A:1003023923056

Garson, G. D. (2013). Factor analysis (statistical associates blue book series). Asheboro, NC: Statistical Publishing Associates.

Gill, R. (2014). Academics, cultural workers and critical labour studies. Journal of Cultural Economy, 7(1), 12-30.

Goolnik, G. (2012). Change management strategies when undertaking e-learning initiatives in higher education. Journal of Organizational Learning \& Leadership, 10(2), 16-28.

Govender, V., \& Rampersad, R. (2016). Change management in the higher education landscape: A case of the transition process at a South African University. Journal Risk Governance \& Control: Financial Markets \& Institutions, 6(1), 43-51. https:// doi.org/10.4102/sajip.v31i1.186

Guruz, K. (2011). Higher education and international student mobility in the global knowledge economy. Revised and updated 2 nd edition. New York: SUNY Press.

Hair, Jr. J. F., Anderson, R. E., Tatham, R. L., \& Black, W. C. (1995). Multivariate data analyses with readings. Upper Saddle River, NJ: Pearson. 
Hair, Jr, J. F., Black, W. C., Babin, B. J., Anderson, R. E., \& Tatham, R. L. (2010). SEM: An introduction. Multivariate data analysis: A global perspective. Upper Saddle River, NJ: Pearson.

Hall, M. (2016). South Africa's student protests have lessons for all universities. Retrieved from https://www.theguardian.com/higher-education-network/2016/ mar/03/south-africas-student-protests-have-lessons-for-all-universities.

Heleta, S. (2016). Decolonisation of higher education: Dismantling epistemic violence and Eurocentrism in South Africa. Transformation in Higher Education, 1(1), 1-8. https://doi.org/10.4102/the.v1i1.9

Herbst, T. H., \& Conradie, P. D. (2011). Leadership effectiveness in higher education Managerial self-perceptions versus perceptions of others. SA Journal of Industria Psychology, 37(1), 01-14. https://doi.org/10.4102/sajip.v37i1.867

Herman, J. H. (2012). Faculty development programs: The frequency and variety of professional development programs available to online instructors. Journal of Asynchronous Learning Networks, 16(5), 87-106. https://doi.org/10.24059/olj. v16i5.282

Hinkin, T. R. (1995). A review of scale development practices in the study of organizations. Journal of Management, 21(5), 967-988.

Hinkin, T. R., Tracey, J. B., \& Enz, C. A. (1997). Scale construction: Developing reliable and valid measurement instruments. Journal of Hospitality \& Tourism Research, 21(1), 100-120. https://doi.org/10.1177/109634809702100108

Hunt, H. D., Davies, K., Richardson, D., Hammock, G., Akins, M., \& Russ, L. (2014). It is (more) about the students: Faculty motivations and concerns regarding teaching online. Online Journal of Distance Learning Administration, 17(2), 62-71.

Ichikawa, M., \& Konishi, S. (1995). Application of the bootstrap methods in factor analysis. Psychometrika, 60(1), 77-93. https://doi.org/10.1007/BF02294430

Jackson, L. T., Rothmann, S., \& Van de Vijver, F. J. (2006). A model of work-related wellbeing for educators in South Africa. Stress and Health: Journal of the International Society for the Investigation of Stress, 22(4), 263-274.

Johnson, T., Wiśniewski, M. A., Kuhlemeyer, G., Isaacs, G., \& Krzykowski, J. (2012). Technology adoption in higher education: Overcoming anxiety through faculty bootcamp. Journal of Asynchronous Learning Networks, 16(2), 63-72. https://doi. org/10.24059/olj.v16i2.240

Kahn, W. A. (1990). Psychological conditions of personal engagement and disengagement at work. Academy of Management Journal, 33(4), 692-724.

Kamanzi, B. (2016). Decolonising the curriculum: The silent war for tomorrow. Retrieved from http://www.che.ac.za/sites/default/files/publications/BrieflySpeaking\%20 from http://www.che.ac.za/sites/default/files/pub

Kamsteeg, F. (2016). Transformation and self-identity: Student narratives in postapartheid South Africa. Transformation in Higher Education, 1(1), 1-10. https:// doi.org/10.4102/the.v1i1.10

Kapuścinski, A. N., \& Masters, K. S. (2010). The current status of measures of spirituality: A critical review of scale development. Psychology of Religion and Spirituality, 2(4), 191. https://doi.org/10.1037/a0020498

Karasek, Jr, R. A. (1979). Job demands, job decision latitude and mental strain Implications for job redesign. Administrative Science Quarterly, 24, 285-308. https://doi.org/10.2307/2392498

Kenny, J. D., \& Fluck, A. E. (2014). The effectiveness of academic workload models in an institution: A staff perspective. Journal of Higher Education Policy and Management, 36(6), 585-602. https://doi.org/10.1080/1360080X.2014.957889

Kim, M., Kim, Y., \& Schmidt, P. (2007). On the accuracy of bootstrap confidence intervals for efficiency levels in stochastic frontier models with panel data. Journa of Productivity Analysis, 28(3), 165-181. https://doi.org/10.1007/s11123-0070058-2

King, R., Marginson, S., \& Naidoo, R. (Eds.). (2011). Handbook on globalization and higher education. Cheltenham: Edward Elgar Publishing.

Kinman, G., \& Jones, F. (2003). 'Running up the down escalator': Stressors and strains in UK academics. Quality in Higher Education, 9(1), 21-38.

Kinman, G., Jones, F., \& Kinman, R. (2006). The well-being of the UK academy, 1998-2004. Quality in Higher Education, 12(1), 15-27.

Kline, B. (2011). The Bayesian and frequentist approaches to testing a one-sided hypothesis about a multivariate mean. Journal of Statistical Planning and Inference, 141(9), 3131-3141. https://doi.org/10.1016/j.jspi.2011.03.034

Kline, R. B. (2005). Principles and practice of structural equation modeling (2nd edn.). New York: The Guilford Press.

Knight, J. (2004). Internationalization remodeled: Definition, approaches, and rationales. Journal of Studies in International Education, 8(1), 5-31. https://doi. rationales. Journal of Studies in Inter
org/10.1177/1028315303260832

Langford, P. H. (2010). Benchmarking work practices and outcomes in Australian universities using an employee survey. Journal of Higher Education Policy and Management, 32(1), 41-53. https://doi.org/10.1080/13600800903440543

Le Grange, L. L. L. (2011). Sustainability and higher education: From arborescent to rhizomatic thinking. Educational Philosophy and Theory, 43(7), 742-754. https:// doi.org/10.1111/j.1469-5812.2008.00503.x

Le Grange, L. L. L. (2016). Decolonising the university curriculum. South African Journal of Higher Education, 30(2), 1-12.

LePine, J. A., Podsakoff, N. P., \& LePine, M. A. (2005). A meta-analytic test of the challenge stressor-hindrance stressor framework: An explanation for inconsistent relationships among stressors and performance. Academy of Management Journal, 48(5), 764-775. https://doi.org/10.5465/amj.2005.18803921

Luthans, F. (2002). Positive organizational behavior: Developing and managing psychological strengths. Academy of Management Perspectives, 16(1), 57-72
https://doi.org/10.5465/ame.2002.6640181
Lyons, M., \& Ingersoll, L. (2010). Regulated autonomy or autonomous regulation? Collective bargaining and academic workloads in Australian universities. Journa of Higher Education Policy and Management, 32(2), 137-148. https://doi.org/ of Higher Education Policy and

MacDonald, W. (2003). The impact of job demands and workload on stress and fatigue. Australian Psychologist, 38(2), 102-117. https://doi.org/10.1080/000500 60310001707107

Mahomed, F. E., \& Naude, J. L. P. (2006). Occupational stress and strain of support staff at a higher education institution in the North West Province. South African Journal of Higher Education, 20(1), 89-102. https://doi.org/10.4314/sajhe.v20i1.25560

May, R., Strachan, G., \& Peetz, D. (2013). Workforce Development and Renewal in Australian Universities and the Management of Casual Academic Staff. Journal of University Teaching and Learning Practice, 10(3), 1-24.

Mbembe, J. A. (2016). Decolonizing the university: New directions. Arts and Humanities in Higher Education, 15(1), 29-45. https://doi.org/10.1177/1474022215618513

McKaiser, E. (2016). It's time to decolonise Afrikaans. IOL News. Retrieved from https://www.iol.co.za/news/its-time-to-decolonise-afrikaans-2033764.

Mkhize, N., 2015, 'Anger over Rhodes vindicates Mamdani', Business Day, Retrieved from http://www.bdlive.co.za/opinion/columnists/2015/04/07/anger-over-rhodesvindicates-mamdani.

Mostert, F. F., Rothmann, S., Mostert, K., \& Nell, K. (2008). Outcomes of occupational stress in a higher education institution. Southern African Business Review, 12(3), 102-127.

Mouton, N., Louw, G. P., \& Strydom, G. L. (2012). A historical analysis of the postapartheid dispensation education in South Africa (1994-2011). The Internationa Business \& Economics Research Journal (Online), 11(11), 1211. https://doi.org/ 10.19030/iber.v11i11.7369

Munro, G., O'Meara, P., \& Kenny, A. (2016). Paramedic transition into an academic role in universities: A demographic and qualification survey of paramedic academics in Australia and New Zealand. Irish Journal of Paramedicine, 1(2), 1-9. https://doi.org/10.32378/ijp.v1i2.17

Ng'ethe, J. M., Namusonge, G. S., \& Iravo, M. A. (2012). Influence of leadership style on academic staff retention in public universities in Kenya. International Journal of Business and Social Science, 3(21), 297-302.

Nowlis, S. M., Kahn, B. E., \& Dhar, R. (2002). Coping with ambivalence: The effect of removing a neutral option on consumer attitude and preference judgments. Journal of Consumer Research, 29(3), 319-334. https://doi.org/10.1086/344431

Nunnally, J. C., \& Bernstein, I. H. (1994). Psychometric theory (McGraw-Hill Series in Psychology). New York: McGraw-Hill.

Oliver, R., \& Herrington, J. (2001). Teaching and learning online: A beginner's guide to e-learning and e-teaching in higher education. Perth, WA: Centre for Research in Information Technology and Communications.

Olivier, A. L., \& Rothmann, S. (2007). Antecedents of work engagement in a multinational company. SA Journal of Industrial Psychology, 33(3), 49-56. https:// doi.org/10.4102/sajip.v33i3.396

Oshagbemi, T. (2000). Gender differences in the job satisfaction of university teachers. Women in Management Review, 15(7), 331-343. https://doi.org/10.1108/ 09649420010378133

Pallant, J. (2011). SPSS Survival manual: A step by step guide to data analysis using SPSS. Sydney, NSW: Allen \& Unwin.

Palloff, R. M., \& Pratt, K. (2015). Building learning communities in cyberspace. San Francisco, CA: Jossey-Bass.

Petersen, T. (2016). Protestors attempt Stellies exam disruption. News 24, 10 August 2017. https://www.news24.com/SouthAfrica/News/protesters-attempt-stelliesexam-disruption-20161102.

Phillips, J. J., \& Connell, A. O. (2003). Managing employee retention: A strategic accountability approach. Burlington: Franklin Covey.

Pienaar, C., \& Bester, C. (2006). Topical career dilemmas of academic staff during the early career phase within a changing South African higher education institution. South African Journal of Education, 26(4), 581-594.

Pijoos, I. (2016). CR Swart statue has fallen. News24, 18 January 2018. http://www. news24.com/SouthAfrica/News/cr-swart-statue-has-fallen-20160223.

Pillay, S. (2015). Decolonising the university, Africa is a Country. Retrieved from http:// africasacountry.com/2015/06/decolonizing-the-university/.

Podsakoff, N. P., LePine, J. A., \& LePine, M. A. (2007). Differential challenge stressorhindrance stressor relationships with job attitudes, turnover intentions, turnover, and withdrawal behavior: A meta-analysis. Journal of Applied Psychology, 92(2), 438. https://doi.org/10.1037/0021-9010.92.2.438

Power, T. M., \& Morven-Gould, A. (2011). Head of gold, feet of clay: The online learning paradox. The International Review of Research in Open and Distributed Learning, 12(2), 19-39. https://doi.org/10.19173/irrodl.v12i2.916

Rainnie, A, Goods, C., Barns, S., \& Burgess, J. (2013) The challenges of working in Australian academia: An introduction. Labour \& Industry: A Journal of the Socia and Economic Relations of Work, 23(3), 191-199. https://doi.org/10.1080/10301 763.2013.839080

Ramrathan, L. (2016). Beyond counting the numbers: Shifting higher education transformation into curriculum spaces. Transformation in Higher Education, 1(1), 1-8. https://doi.org/10.4102/the.v1i1.6

Rantao, K. (2015). \#FeesMustFall - Demanding an affordable Bill of Rights. Retrieved from https://www.news24.com/Tags/Topics/university_protests. 
Roberts, J. A., Lapidus, R. S., \& Chonko, L. B. (1997). Salespeople and stress: The moderating role of locus of control on work stressors and felt stress. Journal of Marketing Theory and Practice, 5(3), 93-108. https://doi.org/10.1080/10696679. Marketing Theory
1997.11501773

Rothmann, S., \& Barkhuizen, N. (2008). Burnout of academic staff in South African higher education institutions. South African Journal of Higher Education, 22(2), 439-456. https://doi.org/10.4314/sajhe.v22i2.25796

Rothmann, S., \& Jordaan, G. M. E. (2006). Job demands, job resources and work engagement of academic staff in South African higher education institutions. SA Journal of Industrial Psychology, 32(4), 87-96. https://doi.org/10.4102/sajip. v32i4.247

Sang, K., Powell, A., Finkel, R., \& Richards, J. (2015). Being an academic is not a 9-5 job: Long working hours and the 'ideal worker' in UK academia. Labour \& Industry: A Journal of the Social and Economic Relations of Work, 25(3), 235-249.

Saunders, M., Lewis, P., \& Thornhill, A. (2009). Research methods for business students. Harlow: Pearson Education.

Schofer, E., \& Meyer, J. W. (2005). The worldwide expansion of higher education in the twentieth century. American Sociological Review, 70(6), 898-920. https://doi. org/10.1177/000312240507000602

Schuster, H. J., \& Finklestein, J. M. (2008). The American faculty: The restructuring of academic work and careers. VA: Johns Hopkins University Press.

Seijts, G. H., \& O'Farrell, G. (2003). Engage the heart: Appealing to the emotions facilitates change. Ivey Business Journal, 67(3), 1-5.

Seligman, M. E., \& Csikszentmihalyi, M. (2000). Positive psychology: An introduction. American Psychological Association, 55(1), 5.

Siegrist, J. (1996). Adverse health effects of high-effort/low-reward conditions. Journa of Occupational Health Psychology, 1(1), 27-41. https://doi.org/10.1037/1076 8998.1.1.27

Siu, C. N. (2013). Extending job demands-resources model: The roles of energy management strategy and recovery experiences in facing differentiated job demands. Retrieved from http://commons.In.edu.hk/soc_etd/34/.

Strobel, J., \& Tillberg-Webb, H. (2009). Applying a critical and humanizing framework of instructional technologies to educational practice. Boston, MA: Springer.

Tabachnick, B. G., \& Fidell, L. S. (2007). Using multivariate statistics. Boston, MA: Pearson Education.
Theron, A. V. S., \& Dodd, N. M. (2011). Organisational commitment in a post-merger situation. South African Journal of Economic and Management Sciences, 14(3), 333-345. https://doi.org/10.4102/sajems.v14i3.100

Tims, M., Bakker, A. B., \& Derks, D. (2013). The impact of job crafting on job demands, job resources and well-being. Journal of Occupational Health Psychology, 18(2), 230-240. https://doi.org/10.1037/a0032141

Van Niekerk, F., \& Geertsema, J. C. (2009). Strategies for university improvement: The research profile change at a South African non-research-intensive university. South African Journal of Higher Education, 23(5), 912-934.

Van Theron, M., Barkhuizen, N., \& Du Plessis, Y. (2014). Managing the academic talent void: Investigating factors in academic turnover and retention in South Africa. SA Journal of Industrial Psychology, 40(1), 1-14. https://doi.org/10.4102/sajip. v40i1.1117

Vandeyar, S. (2010). Shifting selves: Constructing and negotiating academic identities. South African Journal of Higher Education, 24(6), 914-934.

Wamai, N. (2016). Decolonizing the academy: Towards a global movement? University World News Global Edition. Retrieved from http://www.universityworldnews. com/article.php?story=20160524135416842.

Wangenge-Ouma, G. (2012). Tuition fees and the challenge of making higher education a popular commodity in South Africa. Higher Education, 64(6), 831-844. https:// doi.org/10.1007/s10734-012-9531-6

Weijters, B., Cabooter, E., \& Schillewaert, N. (2010). The effect of rating scale format on response styles: The number of response categories and response category labels. International Journal of Research in Marketing, 27(3), 236-247. https:// doi.org/10.1016/j.jiresmar.2010.02.004

Widaman, K. F., Little, T. D., Preacher, K. J., \& Sawalani, G. M. (2011). On creating and using short forms of scales in secondary research. In K. H. Trzesniewski, M. B. Donnellan, \& R. E. Lucas (Eds.), Secondary data analysis: An introduction for psychologists (pp. 39-62). Washington, DC: American Psychological Association.

Williams, B., Onsman, A., \& Brown, T. (2010). Exploratory factor analysis: A five-step guide for novices. Australasian Journal of Paramedicine, 8(3), 794-799. https:// doi.org/10.33151/ajp.8.3.93

Wright, S., Williamson, K., Schauder, D., \& Stockfeld, L. (2003). Choice and constraint in academic work on campus and at home. Labour \& Industry: A Journal of the Social and Economic Relations of Work, 13(3), 19-35. 